\title{
Antroduodenal motility in neurologically handicapped children with feeding intolerance
} Steven L Werlin*

\author{
Address: Department of Pediatrics, The Medical College of Wisconsin and The Children's Hospital of Wisconsin Milwaukee, WI United States of \\ America \\ Email: Steven L Werlin* - swerlin@mail.mcw.edu \\ * Corresponding author
}

Published: 0 I September 2004

BMC Gastroenterology 2004, 4:19 doi:10.1 I86/147I-230X-4-19

This article is available from: http://www.biomedcentral.com/I47I-230X/4/19

(c) 2004 Werlin; licensee BioMed Central Ltd.

This is an open-access article distributed under the terms of the Creative Commons Attribution License (http://creativecommons.org/licenses/by/2.0), which permits unrestricted use, distribution, and reproduction in any medium, provided the original work is properly cited.
Received: 02 May 2004

Accepted: 0I September 2004

\begin{abstract}
Background: Dysphagia and feeding intolerance are common in neurologically handicapped children. The aim is to determine the etiologies of feeding intolerance in neurologically handicapped children who are intolerant of tube feedings.

Methods: Eighteen neurologically handicapped children, followed in the Tube Feeding Clinic at the Children's Hospital of Wisconsin who were intolerant of gastrostomy feedings. The charts of these 18 patients were reviewed. Past medical history, diagnoses, history of fundoplication and results of various tests of gastrointestinal function including barium contrast radiography, endoscopy and antroduodenal manometry were documented.

Results: Five of II children had abnormal barium upper gastrointestinal series. Seven of 14 had abnormal liquid phase gastric emptying tests. Two of 16 had esophagitis on endoscopy. All 18 children had abnormal antroduodenal motility.

Conclusions: In neurologically handicapped children foregut dysmotility may be more common than is generally recognized and can explain many of the upper gastrointestinal symptoms in neurologically handicapped children.
\end{abstract}

\section{Backround}

Oral pharyngeal dysphagia due to disordered swallowing has become increasingly recognized in children with cerebral palsy and other neurodevelopmental disorders. This has led to the increasing use of enteral tube feedings either for full or supplemental nutritional support. Symptoms of foregut dysmotility, such as vomiting, retching gagging and bloating, are often associated with tube feeding in neurologically handicapped children [1-4]. Previous studies have demonstrated that recurrent vomiting, aspiration and/or failure to thrive may be present in as many as 10$15 \%$ of institutionalized patients with psychomotor retar- dation. Antroduodenal motor function has been little studied in such children $[5,6]$.

In order to elucidate the mechanisms behind these symptoms we reviewed the charts of a group of children followed in the Tube Feeding Clinic at the Children's Hospital of Wisconsin with neurological dysfunction, who were intolerant of tube feedings and who had undergone antroduodenal motility studies as part of their evaluations. 
Table I: Patient population

\begin{tabular}{|c|c|c|c|c|c|c|c|c|c|c|c|c|}
\hline \multirow{2}{*}{$\begin{array}{l}\text { Patient } \\
\text { Number }\end{array}$} & \multirow{2}{*}{$\begin{array}{c}\text { Age } \\
(y)\end{array}$} & \multirow[t]{2}{*}{ Diagnosis } & \multirow[t]{2}{*}{ Symptoms } & \multirow{2}{*}{$\begin{array}{l}\text { Feeding } \\
\text { Route }\end{array}$} & \multirow[t]{2}{*}{ UGI } & \multirow{2}{*}{$\begin{array}{c}\text { Gastric } \\
\text { Emptying }\end{array}$} & \multirow[t]{2}{*}{ EGD } & \multirow[t]{2}{*}{ PEG } & \multirow{2}{*}{$\begin{array}{c}\text { Fundopli } \\
\text { cation }\end{array}$} & \multirow[t]{2}{*}{ Other } & \multicolumn{2}{|c|}{ Medications } \\
\hline & & & & & & & & & & & H2RA & $\begin{array}{c}\text { Cisapr } \\
\text { ide }\end{array}$ \\
\hline I & 9 & CP GER & $\begin{array}{l}\text { vomiting } \\
\text { retching }\end{array}$ & oral & $\begin{array}{c}\text { paraesophageal } \\
\text { hernia }\end{array}$ & normal & normal & & + & $\begin{array}{l}\text { gastric } \\
\text { bezoar }\end{array}$ & & \\
\hline 2 & 4 & $\begin{array}{l}\text { feeding } \\
\text { aversion }\end{array}$ & $\begin{array}{l}\text { vomiting } \\
\text { retching }\end{array}$ & gastrostomy & $\begin{array}{l}\text { esophageal } \\
\text { dysmotility }\end{array}$ & ND & esophagitis & + & & & + & + \\
\hline 3 & 3 & $\begin{array}{l}\text { Down's } \\
\text { syndrome }\end{array}$ & $\begin{array}{l}\text { gagging } \\
\text { retching }\end{array}$ & gastrostomy & normal & delayed & normal & & + & & & \\
\hline 4 & 2 & $\begin{array}{l}\text { cerebral } \\
\text { dysgenesis } \\
\text { seizures }\end{array}$ & Irritability & jejunostomy & GER & delayed & esophagitis & + & & & & $\begin{array}{c}\text { omepr } \\
\text { azole }\end{array}$ \\
\hline 5 & 5 & $\begin{array}{l}\text { chromosome } \\
\text { 19 deletion, } \\
\text { GER subglotic } \\
\text { stenosis }\end{array}$ & retching & gastrostomy & normal & normal & ND & & + & & & \\
\hline 6 & 4 & hydrocephalus & retching & gastrostomy & normal & normal & normal & + & + & & + & \\
\hline 7 & I & $\mathrm{CP}$ & irritability & gastrostomy & $\begin{array}{c}\text { paraesophageal } \\
\text { hernia }\end{array}$ & normal & normal & & + & & + & + \\
\hline 8 & $2 \mathrm{I} / 2$ & $\begin{array}{l}\text { cerebral } \\
\text { atrophy } \\
\text { recurrent } \\
\text { aspiration } \\
\text { pneumonia }\end{array}$ & vomiting & gastrostomy & GER & normal & normal & + & & & + & + \\
\hline 9 & 2 & $\begin{array}{l}\text { diphragmatic } \\
\text { hernia GER }\end{array}$ & vomiting & jejunostomy & GER & delayed & ND & + & & $\begin{array}{l}\text { surgical } \\
\text { jejunost } \\
\text { omy }\end{array}$ & + & + \\
\hline 10 & 5 & $\begin{array}{c}\text { CP spina } \\
\text { bifida }\end{array}$ & $\begin{array}{l}\text { retching } \\
\text { bloating } \\
\text { constipation }\end{array}$ & jejunostomy & normal & normal & normal & & + & $\begin{array}{l}\text { surgical } \\
\text { jejunost } \\
\text { omy }\end{array}$ & + & + \\
\hline 11 & 9 & $\begin{array}{l}\text { Floating } \\
\text { Harbour } \\
\text { syndrome }\end{array}$ & $\begin{array}{l}\text { retained } \\
\text { food } \\
\text { vomiting }\end{array}$ & oral & ND & rapid & $\begin{array}{l}\text { retained } \\
\text { food }\end{array}$ & + & + & & + & + \\
\hline 12 & 17 & $\begin{array}{l}\text { mitochondrial } \\
\text { disease }\end{array}$ & $\begin{array}{l}\text { vomiting } \\
\text { diarrhea } \\
\text { retching } \\
\text { gagging } \\
\text { bloating }\end{array}$ & gastrostomy & $\begin{array}{l}\text { esophageal } \\
\text { dysmotility }\end{array}$ & delayed & normal & & + & & + & + \\
\hline 13 & 3 & CP GER & $\begin{array}{l}\text { retching } \\
\text { gagging }\end{array}$ & gastrostomy & ND & normal & normal & & + & & & + \\
\hline 14 & 6 & $\begin{array}{c}\text { charge } \\
\text { syndrome } \\
\text { chromosome } \\
\text { I } 3 \text { Deletion }\end{array}$ & $\begin{array}{l}\text { retching } \\
\text { gagging }\end{array}$ & gastrostomy & normal & normal & esophagitis & & + & & + & + \\
\hline 15 & 2 & $\begin{array}{c}\mathrm{CP} \\
\text { hepatoblasom } \\
\mathrm{a}\end{array}$ & vomiting & gastrostomy & $\begin{array}{c}\text { paraesophageal } \\
\text { hernia }\end{array}$ & delayed & normal & & + & $\begin{array}{c}\text { Nissen } \\
\text { breakdo } \\
\text { wn liver } \\
\text { resectio } \\
\text { n } \\
\text { pyloropl } \\
\text { asty }\end{array}$ & + & + \\
\hline 16 & 1 & $\mathrm{CP}$ & vomiting & gastrostomy & GER & delayed & esophagitis & $\begin{array}{c}\text { surgical } \\
\text { gastrosto } \\
\text { my }\end{array}$ & - & $\begin{array}{l}\text { pyloropl } \\
\text { asty }\end{array}$ & + & + \\
\hline 17 & 2 & $\begin{array}{l}\text { feeding } \\
\text { aversion }\end{array}$ & vomiting & gastrostomy & normal & + & normal & + & & & + & + \\
\hline 18 & 10 & $\begin{array}{l}\mathrm{CP} \text { seizures } \\
\text { hydrocephalus }\end{array}$ & $\begin{array}{l}\text { vomiting } \\
\text { retching } \\
\text { gagging } \\
\text { bloating }\end{array}$ & TPN & + & + & & & + & & + & + \\
\hline
\end{tabular}

GER: gastroesophageal reflux CP: cerebral palsy: NE: not done TPN: total parenteral nutiriton

\section{Methods}

The charts of 18 neurologically handicapped children (mean age 4 years, range $1-10$ years; 10 males) with dysphagia and symptoms of foregut motility were reviewed. The symptoms, underlying disorders, feeding route, the presence of fundoplication, and the use of prokinetic agents and $\mathrm{H}_{2}$ b1receptor antagonists are summarized in Table 1. All except one patient were completely or par- tially fed enterally. One patient ate orally but required frequent venting of his gastrostomy.

Following an overnight fast, antroduodenal motility studies were performed using a multilumen catheter with 8 recording ports spaced $2.5-5 \mathrm{~cm}$ apart, passed through the gastrostomy either under fluoroscopic guidance or endoscopically, connected to a low compliance, pneumohydraulic capillary infusion system (Arndorfer Medical 
Specialties, Greendale, WI) and a computerized motility system (Redtech, Calabasas, CA). Fasting activity was recorded for 3-4 hours. Erythromycin $(1 \mathrm{mg} / \mathrm{kg})$ was given intravenously over 10 minutes and the recording continued for another hour. Octreotide $(0.5 \mathrm{mcg} / \mathrm{kg})$ was then given intravenously over 5 minutes. 45 minutes later a liquid meal was given followed by an additional 2-3 hour recording period. The meal varied and consisted of the usual formula and volume given at home. Patients receiving jejunal feedings or TPN were given a bolus gastrostomy feeding. In the one patient receiving TPN, the TPN was discontinued during the study. Prokinetics were stopped at least 48 hours prior to study.

Phase 1 of the MMC was defined as motor quiescence. Phase 2 was defined as the time between Phases 1 and 3 and is characterized by random contractions of varied amplitude and frequency. Phase 3 of the MMC is characterized by an aborally propagating cluster of repetitive contractions with a frequency of 11-13/minute in the duodenum and $3 /$ minute in the antrum with a duration of 3-10 minutes. The tracings were analyzed by visual inspection.

This study was approved by the Research and Publications Committee/Human Rights Review Board of the Children's Hospital of Wisconsin and the Institutional Review Board of the Medical College of Wisconsin.

\section{Results}

Eleven children had had recent upper GI series. Of these 5 were normal, 3 had gastroesophageal reflux and 3 had paraesophageal hernias (all following fundoplications), 1 had a bezoar and 1 had esophageal dysmotility. Fourteen patients had liquid phase gastric emptying studies. Of these 7 were normal, 6 had delayed emptying and 1 had rapid emptying. Two of 16 patients who had had recent endoscopies had esophagitis, 14 were normal. The diagnoses and clinical histories of the patients are summarized in Table 1. Twelve of the 18 patients had had a fundoplication and 9 of the 12 had had a pyloroplasty. Indications for fundoplication were frequently poorly described in the medical records but typically included vomiting and feeding intolerance. The incidence of symptoms such as retching and sweating could not be determined

No patients had a normal antroduodenal motility study (Figures 1,2,3). In the fasting state 12/18 failed to have phase 3 of the MMC. Eight had predominantly phase 2 activity and did not demonstrate normal fasting phase 1. Nine had non-propagating clusters. One had MMCs that propagated in a retrograde fashion.

Following erythromycin eight had a normal response consisting of antral contractions with a frequency of $3 / \mathrm{min}$ followed by phase 3 like activity in the duodenum. Three patients had no response and seen had abnormal responses consisting of abnormal clusters in three, no antral response in three and no duodenal response in three.

Fourteen patients had a normal response to octreotide consisting of cessation of antral activity and the development of phase 3 activity in the duodenum. Two patients had continued antral contractions and two did not develop phase 3 duodenal activity. These patients had non-propagating duodenal clusters.

Fourteen patients had normal postprandial phase 2-like activity. Eight developed premature phase 3 activity within 30 minutes following the meal. Seven patients failed to develop phase 3 activity during the 2-3 hour postprandial monitoring period and seven had no antral contractions in the postprandial monitoring period. One patient had a retrograde MMC.

Three patients developed severe pain or irritability associated with antral or duodenal contractions following erythromycin [2] or octreotide [1]. There was no correlation between any constellation of symptoms and manometric abnormalities.

\section{Conclusions}

Foregut dysmotility is common in children with neurodevelopmental disorders such as cerebral palsy [1-4]. Up to $75 \%$ of institutionalized children with psychomotor retardation have GER [7-11]. A number of investigators have reported that neurologically handicapped children have abnormalities of lower esophageal function $[12,13]$. Delayed gastric emptying is common in such patients $[1,2]$. Many of these patients undergo fundoplication. Continued symptoms of GER following fundoplication or the development of new symptoms such as retching and gagging suggests that a more generalized foregut motility disorder is present in many of these patients [5]. The rates of complications of surgical treatment of GER that might relate to foregut dysmotility include breakdown of the wrap $(0.9-13 \%)$ and the gas bloat syndrome (1.9-8\%) [14]. Other complications not reported in enough detail to estimate complication rates include dumping, and gastroparesis.

Ravelli and Milla have shown that gastric electrical activity as measured by the electrogastrogram (EGG) was abnormal in 31/50 neurologically handicapped children [2]. Eleven of 18 patients who were symptomatic after fundoplication had gastric dysrhythmias. Richards et al showed that neurologically impaired children with pallor, sweating, retching or forceful vomiting preoperatively were at high risk for postoperative retching and vomiting. 


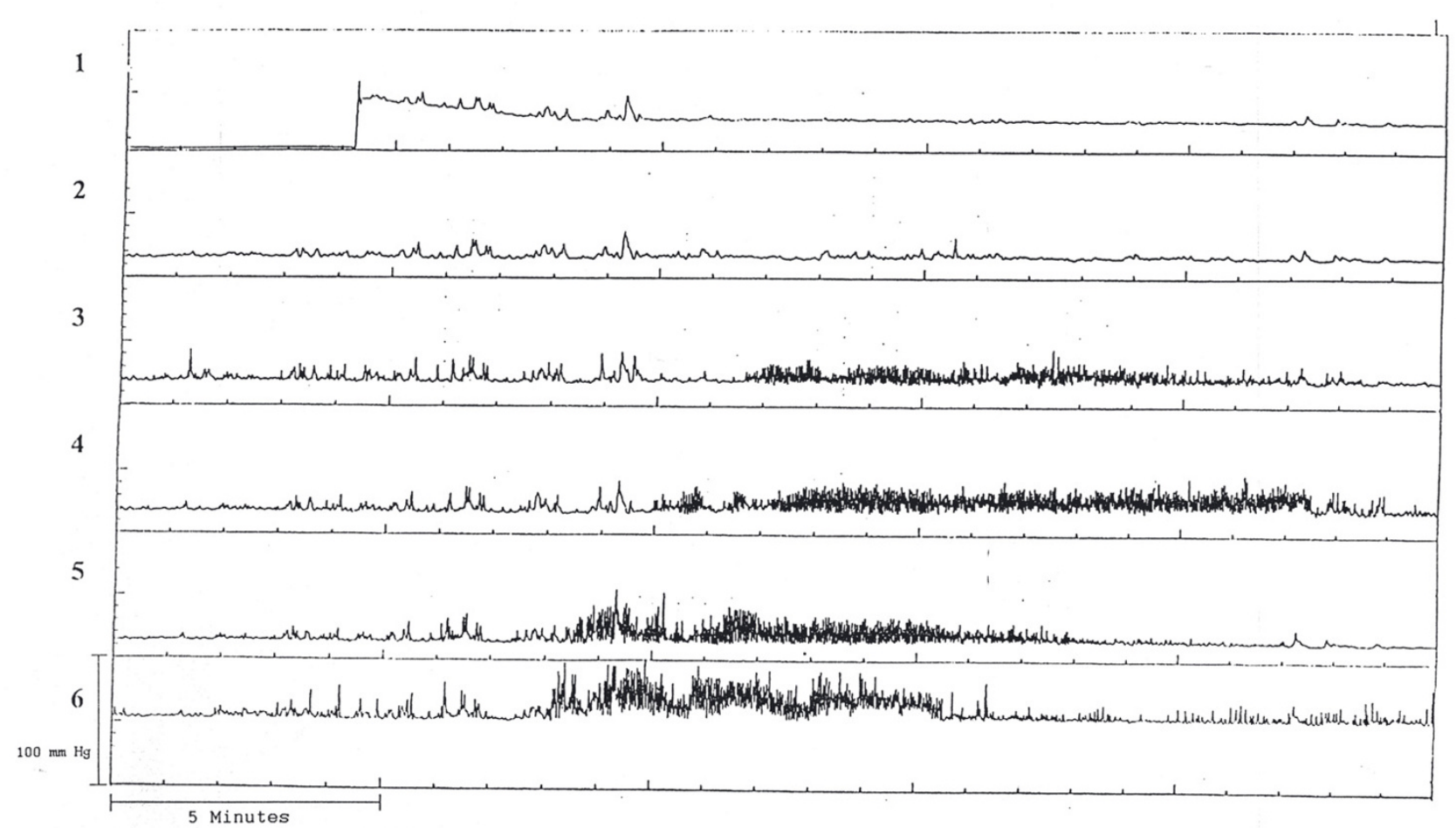

Figure I

An 8-year-old boy who was TPN dependent demonstrates reverse peristalsis. Note lack of antral contractions. Channel I-2 antrum; 3-6 duodenum.

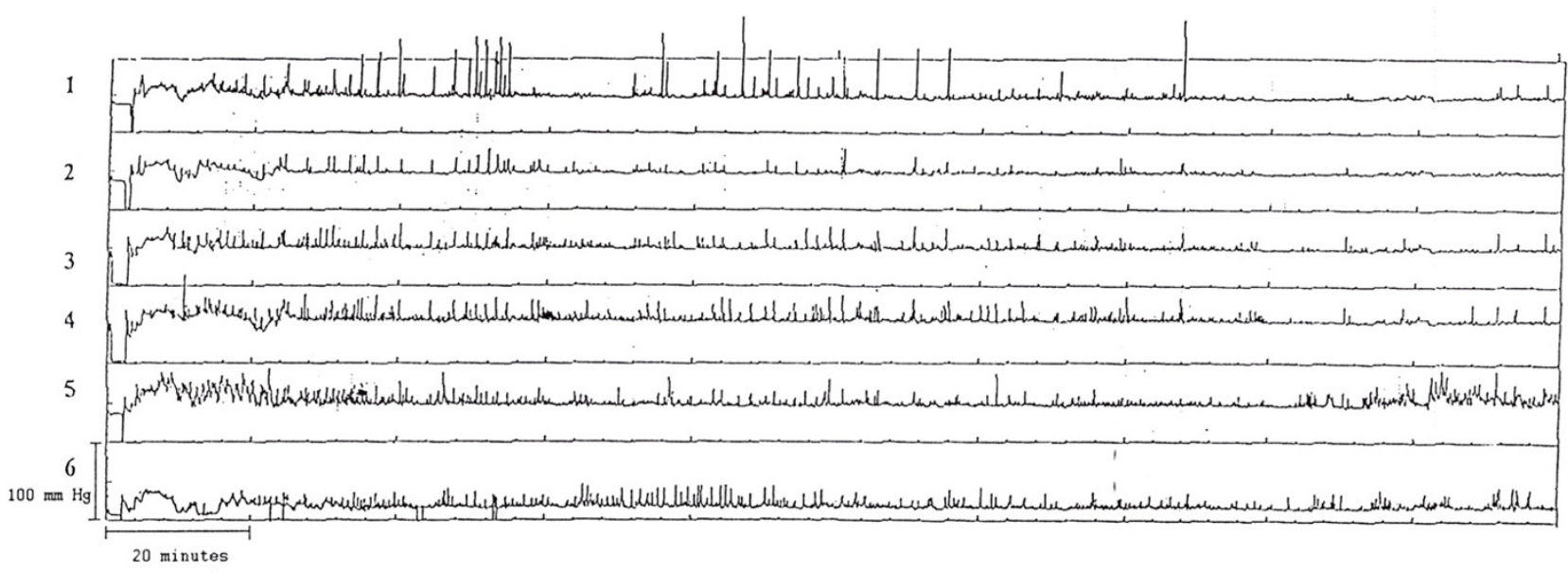

\section{Figure 2}

Lack of fasting phase 3 activity during a 3 hour monitoring period in an 8-year-old boy. He also had no phase 3 like activity following erythromycin. Channel I antrum; 2-6 duodenum. 


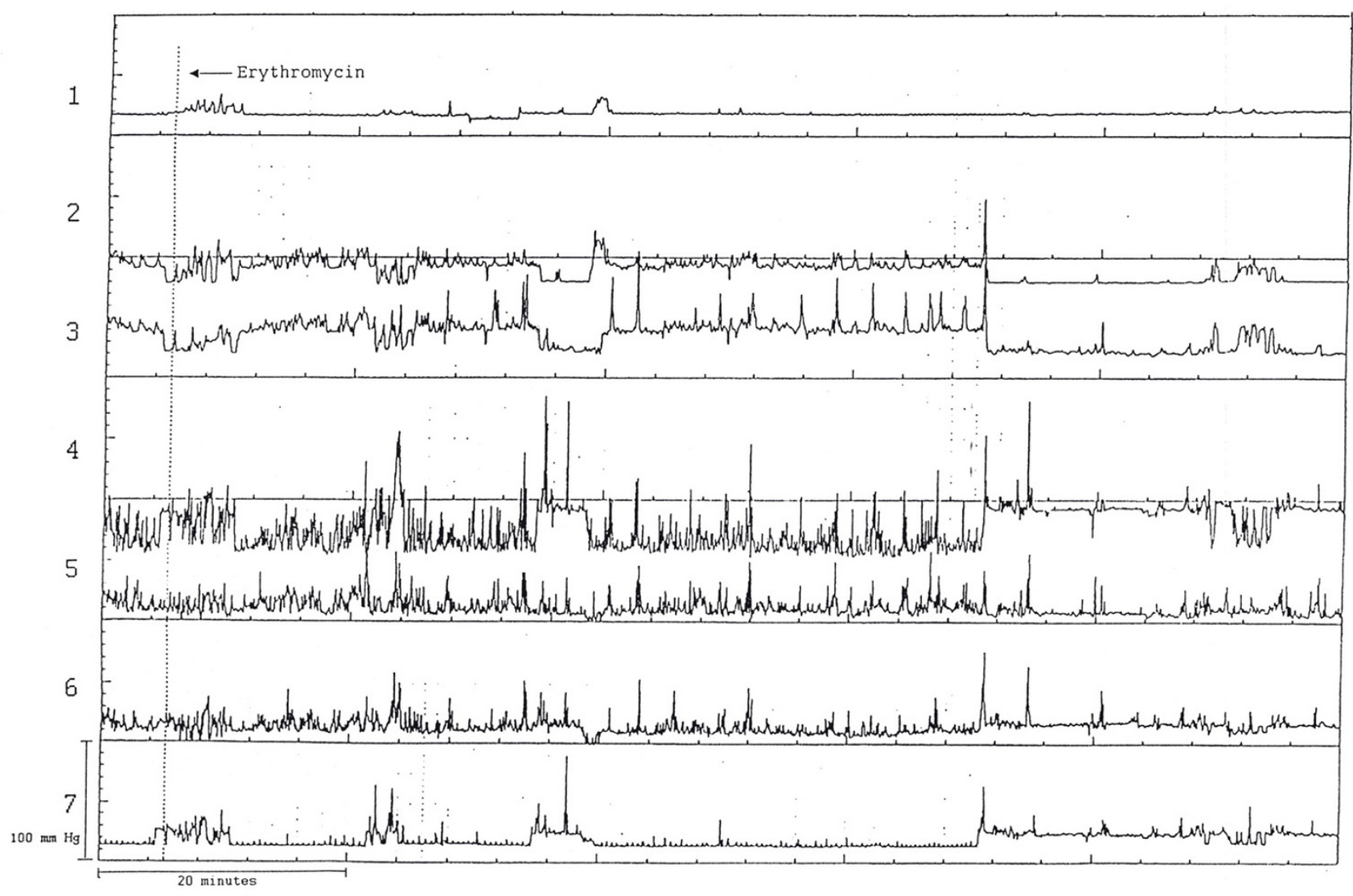

Figure 3

Lack of responsiveness to erythromycin in a 3-year-old boy with feeding aversion. This patient also had postprandial hypomotility. Channels I stomach; 2-3 antrum; 4-7 duodenum.

They hypothesized that these symptoms were indicative of activation of the emetic reflex and that children with these symptoms had a more generalized disorder than those children without such symptoms [15].

In a previous study we compared gastric electrical activity as measured by EGG in a group of neurologically handicapped children who were tolerant of their tube feedings to a group that were intolerant or symptomatic during tube feedings [16]. The percentage of children in each group who had undergone fundoplication was the same. We found that although the percentage of time that normogastria, bradygastria and tachygastria were present was not different in the 2 groups, there was a significant difference in the postprandial power between the groups. This finding suggests that symptoms present in these patients such as vomiting, retching and gagging might be due to an underlying foregut motor disorder.
There have been few reports of antroduodenal motility, which have focused on neurologically handicapped children with feeding intolerance. DiLorenzo and colleagues reported that $25 / 28$ children who remained symptomatic following fundoplication had abnormal antroduodenal motility [5]. Similar to our patients a wide variety of abnormalities were found. These authors did not report how many of their patients that had neurological handicaps. Miki et al found that fasting antroduodenal motility was abnormal in 11 neurologically impaired children with symptoms of gastroesophageal reflux [6].

Due to the nature of our patients there are some limitations in the design and interpretation of our study. Because many of our patients had had multiple formula changes, we decided to use the formula, which the child was receiving at the time of the study, so that any symptoms occurring during the studies could not be attributed to a formula change. Bolus feeds were given to all patients 
during the study even those who had been receiving drip feeds. The fasting state could not be recorded for 4 hours in all patients, thus it is possible that absence of phase 3 of the MMC in these patients might not be abnormal. Since normal manometry data have not been published for children, non propagating clusters may or may not be normal in our patients.

Since only 12 of our 18 patients had undergone fundoplication, we agree with DiLorenzo et al [5] that these motor abnormalities were not caused by surgery, rather we believe that the underlying motility disorder was more generalized than had been recognized at the time of fundoplication.

In this study we have confirmed that the incidence of foregut dysmotility is very high in neurologically handicapped children with feeding intolerance. Prokinetics and acid suppression did not resolve the symptoms in our patients. Twelve of our 18 patients had had fundoplications and two had undergone two fundoplications in unsuccessful attempts to control what had been thought to be reflux symptoms. While there is no way to know how much abnormal antroduodenal motility contributed to our patient's feeding disorders, following antroduodenal manometry a number of our patients were treated successfully with jejunal feeding, suggesting that while they had foregut dysmotility, midgut motility is normal.

In neurologically handicapped children foregut dysmotility may be more common than is generally recognized and can explain many of the upper gastrointestinal symptoms in neurologically handicapped children. Thus in this patient population generalized foregut dysmotility may mimic reflux and the decision to perform a fundoplication should be made very cautiously and only after a complete evaluation of foregut motility particularly in children with gagging retching and forceful vomiting.

\section{Competing Interests}

None declared.

\section{References}

I. Ravelli AM: Diagnostic and therapeutic approach to vomiting and gastroparesis in children with neurological and neuromuscular handicap. I Pediatr Gastroenterol Nutr 1997, 25:S34-S36.

2. Ravelli AM, Milla PJ: Vomiting and gastroesophageal motor activity in children with disorders of the central nervous system. J Pediatr Gastroenterol Nutr 1998, 26:56-63.

3. Sullivan PB: Gastrointestinal problems in the neurologically impaired child. Baillieres Clin Gastroenterol 1997, I I:529-546.

4. Giudice ED, Staiano A, Capano G, Romano A, Florimonte L, Miele E, Ciarla C, Campanozzi A, Crisanti AF: Gastrointestinal manifestations in children with cerebral palsy. Brain Dev 1999, 2 I:307-3 II.

5. DiLorenzo C, Flores A, Hyman P: Intestinal motility in symptomatic children with fundoplication. J Pediatr Gastroenterol Nutr |99|, I2:169-173.
6. Miki K, Harada T, Kozaiwa K, Tajiri H, Nagai T, Kawahara H, Okada A, Okada S: Antroduodenal motor function and gastrooesophageal reflux in neurologically impaired children, adolescents and young adults. Eur J Pediatr 1998, 157:695.

7. Halpern LM, Jolley SG, Johnson DG: A significant association with central nervous system disease in children. J Pediatr Surg 1991, 26:17I-I73.

8. Reyes AL, Cash AJ, Green SH, Booth IW: Gastroesophageal reflux in children with cerebral palsy. Child Care Health Dev 1993, 19:109-118.

9. Roberts KB: Gastroesophageal reflux in infants and children who have neurodevelopmental disabilities. Pediatr Rev 1996, I7:2II-2I2.

10. Bohmer CJM, Niezen-de Boer MC, Klinkenberg-Knol EC, Deville' WLJM, Nadorp JHSM, Meuwissen SGM: The prevalence of gastroesophageal reflux disease in institutionalized intellectually disabled individuals. Am J Gastroenterol 1999, 94:804-8I0.

II. Bohmer CJM, Niezen-de Boer MC, Klinkenberg-Knol EC, Nadorp JHSM, Meuwissen SGM: Gastro-oesophageal reflux disease in institutionalized intellectually disabled individuals. Neth J Med 1997, 5 I:134-139.

12. Staiano A, Cucchiara S, Del Giudice E, Andreotti MR, Minella R: Disorders of oesophageal motility in children with psychomotor retardation and gastro-oesophageal reflux. Eur J Pediatr 1991, 150:638-64I.

13. Gustafsson PM, Tibbling L: Gastro-oesophageal reflux and oesophageal dysfunction in children and adolescents with brain damage. Acta Paediatr 1994, 83: 1081-1085.

14. Oldham KT: Antireflux surgery,. in: Pediatric surgery and urology: long term outcomes Edited by: Massey M, Stringer M, Moriquand P, Howard T. London, WB Saunders: 189-2II.

15. Heikenen JB, Werlin SL, Brown CW: Electrogastrography in gastrostomy-tube-fed Children. Dig Dis Sci 1999, 44:1293-1297.

16. Richards CA, Milla PJ, Andrews PLR, Spitz L: Retching and vomiting in neurologically impaired children after fundoplication: predictive properative factors. J Pediatr Surg 200I, 36: I 40 I - I 404.

\section{Pre-publication history}

The pre-publication history for this paper can be accessed here:

http://www.biomedcentral.com/1471-230X/4/19/pre pub 